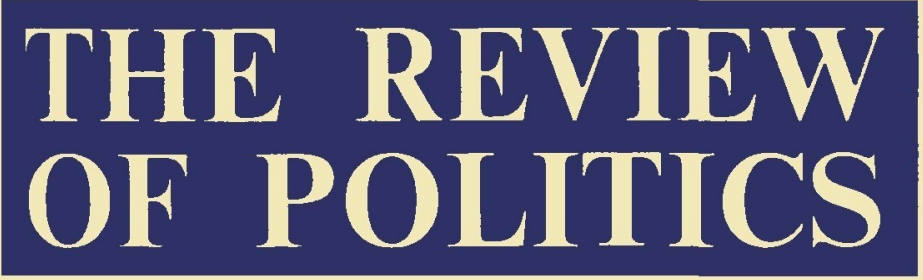

Maoism and Marxism

A. James Gregor and

Maria Hsia Chang

Social Interpretation of Foreign Poliey Mare Trachtenberg

Public Poliey, Morality and Population J. Bryan Hehir

\author{
Ireland and British Labour \\ Fred $D$. Sehneider
}

Montesquieu on Despotism David Young

$$
\text { Vol. } 40 \text { - July, } 1978 \text { - No. } 3
$$

University of Notre Dame

Notre Dame, Indiana 


\title{
THE REVIEW OF PDLITICS
}

\section{FREDARICK J. CROSSON}

\author{
Bditor
}

DENNIS Wm MORAN

Assistant Bditor

\section{A. FITZASIMONS \\ STEPHEN KERTESY}

Advisory Editors

\section{WALDEMAR GURIAN \\ M. A. FITZSIMONS}

Former Editors

Copyright 1978 by the University of Notre Dame. Published quarterly at the University of Notre Dame. Issued each January, April, July and October. Entered as second-class matter April 1, 1939, at the post office at Notre Dame, Indiana, under act of March 2, 1879. Subscriptions: $\$ 10.00$ the year in the United States; foreign $\$ 11.00$; single copies $\$ 3.00$. 


\section{THE REVIEW OF POLITICS}

Published Quarterly by the University of Notre Dame, Indiana

\begin{tabular}{lll}
\hline Vol. 40 & July 1978 & No. 3 \\
\hline
\end{tabular}

A. James Gregor and Maria Hsia Chang

Maoism and Marxism in Comparative Perspective .... 307

Marc Trachtenberg

The Social Interpretation of Foreign Policy ............... 328

J. Bryan Hehir

Development and Population: Policy Perspectives

and Catholic Teaching

Fred D. SGHNeIDER

British Labour and Ireland, 1918-1921: The Retreat to Houndsditch

DAvid Young

Montesquieu's View of Despotism and His Use of

Travel Literature

Reviews:

Edward Fischer: Politics of Propaganda

Donald P. Kommers: Role of the Supreme Court

Joseph M. Siracusa: Russian-American Relations

Michael J. Francis: Chile: A Less Biased View

George Brinkley: From Tsar to Lenin

Alfred M. de Zayas: Political Emigration and the Third Reich 422

M. A. Fitzsimons: Love Story: The American Communist Party 425

Ronald Grigor Suny: Bolsheviks in Siberia

G. D. Loescher: Humanitarian Politics 


\section{Contributors to This Issue}

A. James Gregor is Professor of Political Science at the University of California, Berkeley, and author of The Young Mussolini and the Intellectual Origins of Fascism (in press). MARIA HSIA Chang is Research Assistant in the Department of Political Science, University of California, Berkeley. Marc Trachtenberg is Assistant Professor in the Department of History at the University of Pennsylvania. Rev. J. Bryan Hehir is Associate Secretary, Office of International Justice and Peace, U.S. Catholic Conference. Fred D. SchneIder is Professor of History at Vanderbilt University. David Young has his doctorate from Columbia University and did the research for this article at an NEH workshop; he is currently a postdoctoral fellow at the University of North Carolina.

Edward Fischer served as a military historian in World War II, a public information officer during the Korean conflict and is now a member of the Notre Dame faculty. Donald P. Kommers is Director of the Center for Civil Rights in the Notre Dame Law School. Joseph M. Siracusa is Senior Lecturer of History in Queensland University (Australia). Michael J. Francis teaches Latin American Studies at Notre Dame. George Brinkley directs Notre Dame's Institute for International Studies. Alfred M. DE Zayas is the author of Nemesis at Potsdam. M. A. Fitzsimons, Professor Emeritus, Department of History, University of Notre Dame, is the former Editor of the Review of Politics. Ronald Grigor Suny is Associate Professor of History at Oberlin College. G. D. Loescher is Assistant Dean of Arts and Letters at Notre Dame.

The Review of Polirics, without neglecting the analysis of institutions and techniques, is primarily interested in the philosophical and historical approach to political realities.

The articles in The Review of Politics are indexed in the International Index to Periodicals and the Index of Catholic Periodicals and abstracted in the International Political Science Abstracts. They are abstracted and indexed in ABC POL. SCI. and HISTORICAL ABSTRACTS and Social Sciences Index. 